\title{
Consensus
}

Volume 16

Issue 2 Lutheran Pietism

Article 15

$11-1-1990$

\section{The Rise and Fall of American Lutheran Pietism: The Rejection of an Activist Heritage}

John W. Kleiner

Follow this and additional works at: http://scholars.wlu.ca/consensus

\section{Recommended Citation}

Kleiner, John W. (1990) "The Rise and Fall of American Lutheran Pietism: The Rejection of an Activist Heritage," Consensus: Vol. 16 : Iss. 2 , Article 15.

Available at: http://scholars.wlu.ca/consensus/vol16/iss2/15

This Book Reviews is brought to you for free and open access by Scholars Commons @ Laurier. It has been accepted for inclusion in Consensus by an authorized editor of Scholars Commons @ Laurier. For more information, please contact scholarscommons@wlu.ca. 


\section{The Rise and Fall of American Lutheran Pietism: The Rejection of an Activist Heritage}

Paul P. Kuenning

Macon, GA: Mercer University Press, 1988

$271 \mathrm{pp}$.

Paul P. Kuenning's The Rise and Fall of American Lutheran Pietism argues that the dominant force shaping Lutheranism in North America from the early eighteenth century down to almost the middle of the nineteenth century was Pietism. The Pietism Kuenning has in mind is the classical German Lutheran Pietism associated with the names of Philipp Jacob Spener, who was its founder, and August Hermann Francke, who gave the movement "concrete expression in the form of institutional life" (11). The link between these early founders of Pietism and the later North American developments was Henry Melchior Muhlenberg and his colleagues and successors who were sent out from Halle imbued with the ideals and understandings of the Spener-Francke school of Pietism. Kuenning associates the brief culmination and then rapid fall of American Lutheran Pietism with Samuel Simon Schmucker (1799-1873) and the Franckean Synod (organized in 1837 in New York State), and the discussion of these two subjects in chapters 3-7 constitutes the heart of the book.

Kuenning's thesis that eighteenth and early nineteenth century Lutheranism in North America was essentially Pietist is already a controversial thesis. He gets even more radical and revisionist in his argument that the classical German Pietism which came to be American Lutheran Pietism was characterized by "exuberant ethical activism" (13). This social and ethical activism led Schmucker and the Franckean Synod to espouse the cause of abolitionism in the decades preceding the Civil War (1861-1865), and it was this abolitionism- rather than their doctrinal deviation, as has usually been argued-that caused them to be rejected by their fellow Lutherans, who, in rejecting the leadership of Schmucker and the Franckean Synod, were turning their backs on their activist Pietist heritage. Kuenning's treatment of these topics makes it abundantly clear that he is himself in sympathy with Pietism and would like to see the contemporary Lutheran church in North America recover its Pietist emphases.

As much as one can laud Kuenning's attempt to rehabilitate Pietism and give it "a fair shake" after years of scholarly neglect or summary dismissal on this continent, it is hard to avoid the conclusion that he has pushed his theses to the breaking point. In order to make his case that Pietism was as important as he claims it was, he has to challenge the work of scholars who take a more nuanced position on the subject than he does. Thus, Martin Schmidt, who has been a leading figure in the blossoming of research on Pietism in Germany in the last twenty-five years, is listed as a hostile witness along with people like Albrecht Ritschl and Ernst Troeltsch. This seems to me an unfair assessment of a scholar who must surely count 
as a sympathetic interpreter of Pietism. Similarly, the standard biography of Muhlenberg, William J. Mann's Life and Times of Henry Melchior Muhlenberg (1887), is portrayed by Kuenning as being the work of a champion of Lutheran Orthodoxy who presents Muhlenberg "as an upholder of a strictly orthodox confessionalist theology" (44). In fact, Mann is quite balanced on this question and acknowledges that Muhlenberg was strongly influenced by Pietism which he describes as follows: "Pietism was indeed the form under which in those years warm-hearted godliness almost exclusively existed in Germany....It was the living source from which then proceeded most works of Christian charity, missionary enterprises, care of the orphans, the spreading of the Bible among the masses of the people, and instruction of the neglected. To this school, if we may so call it, Mühlenberg belonged" (393). Do these statements sound like the judgment of a person who was predisposed to reject Pietism and to deny Muhlenberg's relationship to it?

Further, was Pietism-either in its form as classical German Lutheran Pietism or as American Lutheran Pietism-as socially active as Kuenning would have us believe? Kuenning does well to remind us that in its earliest manifestations with Spener and Francke it involved two closely related activities: "First, a deep inner spirituality, centered in Scripture and prayer, with an experience of conversion as its hallmark. Second, an intense outward thrust of missionary and benevolent activity as the inevitable and necessary expression of the New Birth, or living faith" (13). However, the element of "benevolent activity" seems to fade rather quickly as a hallmark of Pietism, and already with Muhlenberg and his successors in North America it is hard for Kuenning to make the case that "benevolent activity" continues to be as important as are the "deep inner spirituality" and the missionary activity. Similarly, Kuenning's arguments linking the ethical activism of the early Pietists with the social and ethical concerns of Schmucker and the Franckean Synod are weak. Although it is clear that Schmucker and the Franckean Synod stand on the shoulders of the earlier Pietists, it seems equally clear that to understand them one must give greater attention to the North American context than Kuenning is willing to do. Issues like abolitionism, the Sunday School movement, temperance, etc. were much more shaped by the North American setting than they were by the Pietist heritage. It is interesting that in the discussion of the nineteenth century developments there are scarcely any references to the Pietist background. If Pietism was the dominant force shaping American Lutheranism until well into the nineteenth century and if this Pietism was as marked by an ethical activism as Kuenning proposes, then one would expect that more Lutherans than Schmucker and the Franckean Synod would have demonstrated such activism; yet Kuenning readily admits that on these social issues these two tended to be voices crying in the wilderness.

The preceding criticisms seem to me to be important challenges to Kuenning's arguments and conclusions. However, I would like them to be interpreted within the framework of a positive appreciation for the book. It is stimulating and well written and directs our attention to some historical 
developments and issues that have not received the attention they deserve. As an essentially revisionist treatment, the book is no doubt intended to be challenging rather than definitive. It deserves to be read and pondered.

John W. Kleiner

Lutheran Theological Seminary

\section{Luther in Context}

\section{David C. Steinmetz}

Bloomington, IN: Indiana University Press, 1986 140 pp. + index, paper

Books and articles about Martin Luther abound today as much as anytime since the beginnings of modern Luther studies in 1883, yet most are disappointing at best. We too often meet only the Luther of legend, either the angelic Luther or the demonic Luther depending on the ideology of the writer, and very seldom are enlightened about why this particular professor of sacred scripture in a backwater German university has had such an impact on theology and church. Even lifelong Lutherans-dare we say, even Lutheran pastors-deal with Luther through a haze of stereotypes.

David Steinmetz has already established a reputation as one of the best historians of Reformation theology working in North America today. He has also shown himself to be a careful and accurate student of Luther's theology in articles and his book Luther and Staupitz. With such a reputation, expectations for new books will always be high. In Luther in Context Steinmetz does not disappoint.

The book is a series of essays which began life as lectures, delivered mostly during 1983, the 500th Anniversary year. These are not the usual jubilee year pablum, though, but meaty explorations of various themes in Luther's theology. Steinmetz is especially strong, as the title implies, in showing Luther in the context of other late-Medieval and Reformation era theologians.

One of Steinmetz' ongoing research interests has been Reformation hermeneutics. That topic appears in essays on Romans 9, Abraham, the Lord's Supper, and Noah. "Luther and the Drunkenness of Noah" is typical. In that essay Steinmetz compares Denis the Carthusian (died 1471), young Luther, old Luther, and modern exegesis. Because the comparison is Denis rather than an author whom Luther cites (such as Nicholas of Lyra or St. Augustine), we see where Luther is typical of his times and where different. In this way an accurate view of Luther the exegete is portrayed.

Steinmetz provides an excellent summary of one of Luther's central theological themes, the hidden God, in an essay by that title. Speaking 